International Journal of Social Science and Economic Research

ISSN: 2455-8834

Volume:05, Issue:10 "October 2020"

\title{
WESTERN ELECTORAL SYSTEMS APPLIED
}

\author{
Shak Bernard Hanish, Ph.D. \\ Foreign Language Department, Yuncheng University, Shanxi, China
}

DOI: 10.46609/IJSSER.2020.v05i10.019 URL: https://doi.org/10.46609/IJSSER.2020.v05i10.019

\begin{abstract}
In this article, I will explain how parliamentary elections are organized in the European countries and the United States. I will explain the winner-take-all electoral system that is used in the United States and the United Kingdom. Almost all other countries are using the proportional representation system or combination of the two systems. Then, I will detail the proportional presentations types in Holland, the Republic of Slovakia, Switzerland, Ireland, and Germany where personal proportional representation is used in some. The demarcating of the boundaries of the district in a single-member area are explains and how some proportional representation systems changed to winner take all and then back to proportionality. Also, voter turnout in Europe is generally much higher than in the United States, and how proportional system allows small groups and minorities more access to political representation and therefore not "wasting" votes as in district systems that choose only one member. Finally, I will evaluate the proposed electoral system with counting districts in Iraq and its advantages, disadvantages, pros, and cons but conclude that the proportional system has far more positive than its negatives, listing the most important drawbacks of the system put forward in the Iraqi House of Representatives.
\end{abstract}

Keywords: Electoral systems, proportional representations, winner-take-all electoral system, mixed-electoral system, Iraqi elections, voter turnout, Western electoral systems.

\section{Introduction}

Many may be surprised that there is only one country, the United Kingdom, which uses a system (the winner-takes-all), where there is one ballot as in the US congressional elections. All other countries (the winner-takes-all) are used with two ballots and not one, proportional representation (proportionality), or a combination of the winner-takes-all and proportionality. Proportionality simply means that the percentage of parliamentary seats received by a party, bloc or group, corresponds to the percentage of support it receives from voters. Here, I will highlight the significant differences in the division of electoral districts in the United States compared to European countries. 


\section{International Journal of Social Science and Economic Research}

ISSN: $2455-8834$

Volume:05, Issue:10 "October 2020"

Most people believe that democracy means free and fair elections. But there are very different systems in this regard that largely determine how the will of the people is transformed into real political outcomes. These electoral systems have been described as "the most manipulative tool in politics" (1).

Parliamentary election systems are the official rules by which parliamentary elections are organized. These rules vary from country to country and affect the success of political parties, positively and negatively. Election rules and regulations, like any other rules, are never neutral.

Americans are accustomed to the simple rules of parliamentary elections. For the U.S. Senate, whoever gets the most votes in his/her state is elected. The same rule applies to the U.S. House of Representatives: whoever wins the most votes in his constituency is elected. For the Senate and the House of Representatives, there is one vote. In Europe, the winner system, which takes everything in a single ballot, is used only in Great Britain, where it is called the "first winner". This system can also be called a single-member constituency, which means that only one member of Parliament is elected to each constituency and that it is sufficient to reach the majority of votes (not a majority of 50 percent +1 ) in order to win the seat. Other European countries use a wide range of rules to elect their own parliaments, but most use a form of proportional representation that allocates parliamentary seats in proportion to popular votes. The election result affects the way the political game is played (2). A politician or political party that succeeds under a set of rules may not succeed within a different group.

In general, European politicians in their parliamentary electoral success rely far more on their political parties than their American colleagues. For U.S. congressional elections, each candidate must fight for himself or herself to be elected. This means organizing a very personal election campaign and raising the necessary funds. Therefore, money is much more important to the success of elections in the United States than in Europe. Parliamentary elections in Europe are also less expensive, with greater restrictions on campaign expenditures.

\section{In Great Britain: Winner takes it all in one ballot}

For the election of members of the House of Commons, Great Britain is divided into several constituencies equal to the number of parliamentary seats - currently 650 - and in each constituency, the candidate with the highest number of votes wins the seat. The winner gets everything, and the loser gets nothing. As in the USA, there is no requirement that the winner reaches an absolute majority of 50 percent +1 . Just the majority of the votes are enough. Thus, for example, with three candidates in a constituency, the winner may receive only 40 percent of the vote, and each of the other candidates may get 30 percent but without any parliamentary seat. 


\section{International Journal of Social Science and Economic Research}

ISSN: $2455-8834$

Volume:05, Issue:10 "October 2020"

The winner's system takes everything strongly biased in favor of the two largest parties in a country. In the U.S. Congress, no third party has been represented too much recently. This is largely due to the electoral system. Under a different electoral system, third parties in the United States would have a better chance of representing Congress. Discrimination against third parties is evident in many general elections, in which the third party has won significant support from voters in particular but has little parliamentary representation, while a major party won only a majority of votes but an overwhelming majority of parliamentary seats.

To fully understand the winner system that takes everything into full, we must also consider the proactive effects. Many voters do not like to "waste" their vote on a party that is expected to have no chance of winning.

\section{In Holland: List of parties in proportional representation}

The basic principle of the list of parties in proportional representation is simple. The party receives parliamentary seats in proportion to its share of the total votes. If parliament wins 100 seats and a party or group wins 10 percent of the total vote, it will get 10 parliamentary seats. If the party wins 1 percent of the vote, it will get one seat. If a party wins 1.5 percent of the vote, its seats will depend on the fractions of seats obtained by the other parties (3).

The Netherlands uses the party list for proportional representation in its simplest form. The Dutch Parliament has 150 members elected from a single constituency at the national level. Political parties provide lists of their candidates, and voters simply choose one of them.

The second step is to consider how parties determine which candidates they will be elected. Each party lists its candidates in the order in which they will be given the seats in which the party will win. For example, if a party wins 30 candidates, they will be the top 30 names on the party's list.

A small group, such as the party's executive committee, usually prepares the party list. The party congress then approves the list, usually without making major changes. By working hard for the party, the candidate expects to have a good ranking on the list. This system strengthens parties by allowing them to reward loyal party members. Some parties have now begun to hold internal elections among party members to determine the serial ranking of the party's list.

In the Netherlands, small parties have the opportunity to win parliamentary representation. With an electoral system of pure proportionality applied to the United States, any group that receives a small percentage of votes, for example, 0.25 percent of the vote cast, will win a seat in the U.S. House of Representatives (one seat out of 435 in the U.S. House of Representatives). The introduction of the Proportional Representation List of the United States Congress will more 
International Journal of Social Science and Economic Research

ISSN: 2455-8834

Volume:05, Issue:10 "October 2020"

closely reflect the diversity and ideas of the American population, and many voters will find a party closer to their preference than they do today in the current bipartisan system.

\section{In the Republic of Slovakia: Proportional representation}

Slovakia, like the Netherlands, the whole country is one electoral district! Most voters vote for political parties, not candidates. Voters vote on the philosophical differences between parties rather than what happens in their region. So, the party politician represents the philosophical interests of all his supporters throughout the country, rather than geographically defined interests.

\section{Switzerland, Ireland, and Germany: Personal proportional representation}

\subsection{Switzerland}

As for the election of the Lower House of Parliament, Switzerland adjusts proportional representation in the list of parties in two important ways. Instead of being a single national constituency, 26 constituencies are corresponding to the 26 Swiss cantons. The seats are divided among the cantons by population. The largest canton, Zurich, elects 34 representatives and the smallest canton elects only one. The existence of 26 constituencies instead of one national constituency is working against small parties.

The Second Swiss Amendment is that voters, not parties, rank candidates. The parties provide a list of names without a hierarchy or preference. Voters only decide for each candidate whether to leave the candidate unchanged or drop the candidate from the list. The total number of names on each voter's list should be higher than the number of seats to be elected from the canton. The voter may also decide not to make any changes to the list at all. In this case, no preference is given to any of the candidates, but votes are counted for the number of seats attributed to the party. Voters may further complicate their list by writing candidates from other parties.

\subsection{Ireland}

Personal proportional representation can also be achieved through a single transferable voting system, with a total of 166 seats, elected from 43 constituencies, and between three and five seats per constituency. In each district, voters rank candidates by preference. For example, if there are four seats in a circle and 100,000 valid votes, the required quota is 100,000 divided by $5+1=$ 20001. If the quota reaches the official announcement of the team, as the count continues, it is clear that he no longer needs other votes and is therefore transferred to the other candidates on his list. If the province has four seats to allocate, the fourth seat cannot be allocated in this way. The candidate with the lowest number of votes is eliminated and his or her votes are transferred to the top candidate in the relevant ballot. 
International Journal of Social Science and Economic Research

ISSN: 2455-8834

Volume:05, Issue:10 "October 2020"

\subsection{Germany}

Germany uses another system of personal proportional representation. Its main advantage is that every German voter receives two votes in his or her ballot, the so-called first and second votes. The first vote is according to the winner who gets everything in one circle. The second is proportional to the list of parties. In 1949, Western powers, particularly Great Britain and the United States of America, urged Germany to adopt a winner-take-all system. However, many German leaders argued that the winners' system could not adequately represent the country's political diversity. So, the winner system that takes everything was defeated (4).

The solution that had been enacted was to elect half of the Bundestag (parliament) with a winner system that took everything and the other half with proportional representation. Both votes are cast on the same day, on the same ballot. For the first vote, the country is divided into small constituencies that correspond to half of the parliamentary seats. In each constituency, the candidate who received the most votes is elected. For the relative part of the election, Germans use a proportional representation of the party list, with the order of candidates carried out by the parties.

Voters are allowed to divide their votes. In a winner's election, they can vote for someone who represents one party, and in proportional representation elections, they can choose a different party. Supporters of the small Free Democratic Party may cast their first ballots for a candidate for one of the two major parties, knowing that their own candidate has virtually no chance of winning the election, but they can still cast their second vote for their party list. Each party receives the same percentage of seats as the second nation, making the German system very relative.

The German system also contains a provision that provides for an electoral threshold against very small parties. This threshold deprives the parliamentary representation of parties that win less than 5 percent of the second vote nationwide if they are unable to win three of the first ones. In the 2013 elections, the populist right-wing Alternative for Germany (IDF) won 4.7 percent of the second vote and failed to win any single constituency. It, therefore, received no parliamentary representation. In the 2005 elections, the SPD, which won its support in eastern Germany, did not win 5 percent nationwide but qualified for parliamentary representation because it won three seats directly.

\section{Demarcating the boundaries of the district in a single-member area and proportional representation systems}

In a constituency system that selects one-member, political success or failure depends largely on how the boundaries of the electoral district are drawn. In the United States of America, in the 


\section{International Journal of Social Science and Economic Research}

ISSN: $2455-8834$

Volume:05, Issue:10 "October 2020"

first year after the 10-year general census, constituencies are redrawn to take into account changes in the number of people living in districts.

In the United States of America, constituencies are appointed, by representatives of state legislatures. This is open to great manipulation. There could be a preference for one political party over another. Sometimes the forms of districts take strange forms and then lead to the joke that in the United States of America it is not that voters choose politicians, but politicians choose voters.

In countries such as the United Kingdom, Canada, or Australia, constituencies are re-established by non-partisan bodies and independent political agencies, consisting of judges, historians, or geographers whose decisions are based on factors such as ensuring that each region is very similar in population and communities must not disintegrate, among other considerations.

\section{Changing electoral systems in France and Italy}

Some countries have changed their electoral systems. In the early 1990s, like the German model, Poland introduced a 5 percent threshold in its proportional electoral system; as a result of this change in election rules, the number of parties in its parliament had been reduced from 29 to six.

\subsection{France}

France exercised proportional representation under its fourth Republic (1946-1958). In 1958, General Charles de Gaulle and his supporters introduced a system that was notable for the fact that there were two separate elections. The second election comes a week after the first. That is why it is called the two-vote system. For parliamentary elections, France is divided into the same number of constituencies as the National Assembly. In order to be elected on the first ballot, the candidate must obtain an absolute majority $(50$ percent +1$)$ of the votes cast in his district. Only candidates who appeared on the first ballot may be included in the second ballot, and all candidates receiving less than 12.5 percent of the first ballot are excluded. This system was changed but immediately after the 1986 elections, the newly elected parliament changed electoral rules to the previous double voting system.

\subsection{Italy}

Italy changed its electoral system in 1993 from the proportional system of the party list to a mixed system, with 75 percent of the members of parliament elected to the winner-take-all system in the constituencies and 25 percent according to the proportional system according to district constituencies. In 2005, the electoral system was changed to a proportional system again. Since then, Italy has remained with proportional representation. 


\section{International Journal of Social Science and Economic Research}

ISSN: $2455-8834$

Volume:05, Issue:10 "October 2020"

The Italian case highlights an important issue: The number of parties, while oftentimes driven by the electoral system, is not necessarily only driven by it. This depends on the number of divisions in society. A society that has many divisions of parties in parliament may have, although the electoral system is the winner takes it all. On the contrary, a relatively representative country could be divided into only one dimension. As a result, there may be only two or three parties represented in Parliament. A prime example of such a society is Austria after World War II and throughout the mid-1980s. In the autumn of 2005, however, 100 percent of the seats were allocated based on proportional representation.

\section{The origins of electoral systems}

As we have seen, the type of electoral system is crucial in understanding the different political outcomes. Is it "fairer" in the sense that it allows small groups and minorities access to political representation? Will it make the political system more democratic because of not "wasting" votes as in district systems that choose only one member?

Electoral systems are directly linked to the process of democratic transition in the countries of the world. The government's policy of "redistributing" the state of the country's economic and political system is a very positive development. In the United Kingdom and the United States of America, which did not wish to see further redistribution, they supported the one-member constituency by choosing an electoral system that would develop their interests in the first place. The majority of European countries that preferred the creation of a welfare state opted for proportional representation to achieve their goals (5). Most political scientists, therefore, view proportional representation as to the best electoral system.

\section{Voter turnout}

Voter turnout in Europe is generally much higher than in the United States of America and is usually in Europe in the 70, 80, or even 90 percent range. In the United States, between 40 and 60 percent, the first is when elections are for Congress alone and the second when presidential and congressional elections are on the same day (6). In general, electoral rules as used in Europe give voters more influence over the results of parliamentary elections than in the United States of America. In many congressional districts, the current president has become so consistent that the challenger has little chance of winning, whether he is a Democratic or a Republican contender. If the voter prefers the Greens, for example, the citizen does not feel represented by any of the candidates and may not be able to vote to stay at home.

Why does The British have a much higher turnout than Americans, even though both practice the winner system and take everything in individual circles? In contrast to the USA, Great Britain has a parliamentary system, not a presidential system for the choice of executive power. Party 


\section{International Journal of Social Science and Economic Research}

ISSN: $2455-8834$

Volume:05, Issue:10 "October 2020"

discipline in the British Parliament is much more important, and in turn, helps mobilize voters on election day. There is scientific evidence that proportional representation systems indicate an increase in voter turnout. The researchers found "compelling evidence" that proportionality (proportional representation) helps voter turnout. Proportionality increases the number of parties, which in turn helps voter turnout. By contrast, safe seats in winner's systems take everything that gives few incentives to voters to vote (7).

Institutions are man-made. Once developed, they lead to relatively predictable results. But they are always subject to major adjustments if the distribution of political power or power balances changes. The questions are: Who should have the power to change electoral rules: parliament, voters, courts, or a combination of the three? And when can it come into effect? Is it when the politicians who make the new rules leave their posts? Or should there be a waiting period for years for the new rules to take effect?

\section{Evaluation of the proposed electoral system with counting districts}

Each electoral system has advantages, disadvantages, pros, and cons. Through my study of these electoral systems applied in the world and other than my knowledge of the history, culture, and diversity of Iraq, I believe that the proportional system has far more positive than its negatives. The use of the proposed constituency system in the House of Deputies (Representatives) has many drawbacks if applied with its pros. If it is applying this way, in short, the most important drawbacks of the system put forward in the House of Representatives are:

1. It is difficult to determine electoral districts where there are districts and areas large or relatively small in number and it is difficult to determine their geographical boundaries impartially or to know their real population because there has been no census for decades in Iraq.

2. Small districts are more vulnerable to the influence of tribal chiefs, clerics, riches, arms owners, influence, and prestige, especially in rural areas or less urban areas.

3. Iraq is by nature a multi-national, multi-religious, multi-denominational society, with small ones distributed over different geographical areas, wasting their electoral vote. The identification of electoral districts will create many problems between the population, groups, and forces in these areas, which we are now indispensable to, especially in the disputed areas of the various Iraqi nationalities. Especially between the Arabs, the Kurds, and Turcoman.

4. It is also not fair to use only one electoral cycle if a candidate does not get a majority of 50+1 percent of the vote. If there are 20 candidates in a district, one of them can only get 20 votes and be considered a winner when the remaining 19 have fewer votes than the first. How can he/she be said to be a legitimate representative of the electoral district and 80 percent did not vote for 


\section{International Journal of Social Science and Economic Research}

ISSN: 2455-8834

Volume:05, Issue:10 "October 2020"

him/her? There must be a second round to compete among the highest voters in the first round for the winner to actually be represented by the constituency. Instead of spending a lot of money for the second round to express people's opinions, this can be avoided by adopting the proportional system.

5. The chances of independents and academic people will be low in tribal and rural areas, but their chances of success will be greater in densely populated and urbanized cities and places.

6. It is difficult to determine the electoral districts for the votes of voters of displaced persons.

7. It is also possible that the adoption of this law of very many districts violates the Iraqi constitution itself, which recognizes that the members of the House of Representatives represent the whole Iraqi people and not a particular district. The adoption of such a system could open the door to objections in the courts, which could delay the holding of elections on time.

\section{References}

1. Sartori, G. (1976). Parties and Party Systems (Cambridge, MA: Cambridge University Press).

2. Duverger, M. (1965) Political Parties: Their Organization and Activities in the Modern State (London: Wiley).

3. Dow, J. K. (2010). Party-System Extremism in Majoritarian and Proportional Election Systems. British Journal of Political Science 41 (2011): 3441-3461.

4. Bawn, K.(1993, November). The Logic of Institutional Preferences: German Electoral Law as a Social Choice Outcome. American Journal of Political Science 37: Ibid., 987-988.

5. Alesina, A. and Glaeser, E. L. (2004). Fighting Poverty in the US and Europe (New York: Oxford University Press.)

6. McCarthy, N. (2006, November).U.S. Trails Most Other Developed Nations In Voter Turnout. Forbes.

7. Crepaz, M.M.L. (2017). European Democracies ( $9^{\text {th }}$ Ed.). Routledge. 